Syifa Al-Qulub 4, 2 (Januari 2020): 49-60

Website: journal.uinsgd.ac.id/index.php/syifa-al-qulub

ISSN-25-8453 (online) dan ISSN-2540-8445 (cetak)

\title{
ZIKIR HENING SUFI DALAM ANALISIS SEMIOTIKA
}

\author{
Hasanuddin Chaer \\ Universitas Mataram, Jalan Majapahit 62, Matram, NTB, Indonesia \\ Email: hasan.unram@gmail.com \\ Ahmad Sirulhaq \\ Universitas Mataram, Jalan Majapahit 62, Matram, NTB, Indonesia \\ Email: ahmad_haq@unram.ac.id
}

\author{
Abdul Rasyad \\ Jl. TGKH. M. Zainuddin Abdul Madjid No. 132 Pancor, Lombok Timur, NTB, Indonesia \\ Email: rasyad.iis@gmail.com
}

\begin{abstract}
The Sufis are practitioners of the science of purification of heart. Sufism is the esoteric or inner dimension of Islam. Sufism can't be explained theoretically, it can only be understood through participation and practice. The activities of the ritual dhikr of Sufi have signs and meanings. The Sign of systems include words, movements, pictures, numbers, and objects. These signs have meaning to convey. The Signs have denotative and connotative meanings.This article uses a descriptive analysis method. We analyze discursive and non-discursive symbols, that is words involving emotions and non-verbal meanings such as Sufi body movements in ritual prayers and dhikr. Dhikr "silence" is a command to observe silence which is the purpose of dhikr silent. The purpose of this article is to open the essence of Sufi and semiotics of tasawwuf as the deepest spiritual teachings of the Prophet Muhammad in achieving of silence of "qolbu mu'min Baitullah".
\end{abstract}

Keywords:

Sufis, dhikr, silence, semiotics

\begin{abstract}
Abstrak
Sufi adalah praktisi ilmu pemurnian hati. Sufisme adalah dimensi esoteris atau batiniah dari Islam. Sufisme bukanlah sesuatu yang dapat dijelaskan secara teoritis, hanya dapat dipahami melalui partisipasi dan praktik. Aktifitas ritual dzikir sufi memiliki tanda dan makna. Sistem tanda meliputi kata, gerakan, gambar, angka, dan objek. Tanda-tanda ini memiliki makna untuk disampaikan. Tanda memiliki makna denotatif dan konotatif. Artikel ini menggunakan metode analisis deskriptif. Kami menganalisis simbol-simbol diskursif dan non-diskursif, yaitu kata-kata yang melibatkan emosi dan makna non-verbal seperti gerakan tubuh sufi dalam do'a ritual dan zikir. Zikir"diam" adalah perintah untuk mengamati keheningan yang merupakan tujuan dari dzikir hening. Tujuan artikel ini membuka esensi sufi dan semiotika tasawwuf sebagai ajaran spiritual terdalam Nabi Muhammad dalam mencapai keheningan "qolbu mu'min baitullah".
\end{abstract}

Kata Kunci:

Sufi, dzikir, hening, semiotika

DOI: http://dx.doi.org/10.15575/saq.v4i2.7308

Received: 2020-01-27; Accepted: 2020-01-27 ; Published: 2020-01-29 


\section{A. PENDAHULUAN}

Kata Arab tasawwuf umumnya didefinisikan oleh penulis Barat sebagai "mistisisme Islam", (Lings, 2005: 15) "dimensi batin didalam Islam" (Burckhardt, 2009: 223; Nasr, 2007: 74). Istilah Arab sufi telah digunakan dalam literatur Islam dengan berbagai arti, baik oleh para pendukung dan penentang tasawuf (Huda, 2003: 1-4). Teks sufi klasik, yang menekankan ajaran dan praktik tertentu dari Al-Qur'an dan Sunnah (ajaran dan praktik teladan Nabi Muhammad), memberikan definisi tasawwuf yang menggambarkan tujuan etis dan spiritual dan berfungsi sebagai alat pengajaran untuk pencapaian mereka. Beberapa sarjana modern telah menggunakan definisi lain Sufisme seperti "intensifikasi keimanan dan praktik Islam" dan "proses mewujudkan cita-cita etis dan spiritual"(Hawting 2002: 661-750). Istilah Sufisme pada awalnya diperkenalkan ke dalam bahasa-bahasa Eropa pada abad ke18 oleh para sarjana orientalis yang memandangnya terutama sebagai doktrin intelektual dan tradisi sastra yang berbeda dengan apa yang mereka lihat sebagai monoteisme Islam yang steril. Dalam penggunaan ilmiah modern istilah ini berfungsi untuk menggambarkan berbagai fenomena sosial, budaya, politik dan agama yang terkait dengan para Sufi.

Menurut Ibnu Arabi Islam adalah agama terbaik karena Muhammad. Ibnu Arabi menganggap bahwa entitas pertama yang ada adalah realitas atau esensi dari simbol Muhammad (diciptakan al-ḥaqiqa alMuhammadiyya). Ibnu Arabi menganggap Muhammad sebagai simbol manusia tertinggi dan penguasa semua makhluk. Karena itu Muhammad adalah simbol utama teladan bagi manusia yang patut ditiru. Ibnu Arabi percaya bahwa atribut dan nama Tuhan dimanifestasikan di dunia ini dan tampilan paling lengkap dan sempurna dari atribut dan nama Ilahi ini terlihat dalam simbol diri Muhammad. Ibnu Arabi percaya bahwa seseorang dapat melihat Tuhan di cermin Muhammad, yang berarti bahwa sifat-sifat Ilahi Allah dimanifestasikan melalui simbol Muhammad. Ibnu Arabi menyatakan bahwa
Muhammad adalah bukti terbaik Tuhan dan dengan mengenal Muhammad seseorang mengenal Tuhan. Ibnu Arabi juga menyatakan bahwa Muhammad adalah penguasa semua umat manusia baik di dunia ini maupun di akhirat.

Dalam pandangan ini, Islam adalah agama terbaik, karena Muhammad adalah Islam. Ibnu Arabi menganggap Muhammad sebagai manusia terbesar dan menyatakan "kebijaksanaan Muhammad adalah pribadi yang unik karena ia adalah makhluk paling sempurna yang ada dalam spesies manusia ini. Karena alasan ini, perintah dimulai dengan dia dan disegel bersamanya. Dia adalah seorang Nabi ketika Adam berada di antara air dan tanah liat, dan struktur unsurnya adalah penutup para Nabi" sehingga menjadi simbol terbaik dari para Nabi (Munn, 1969: 279281). Sufi berpendapat bahwa Muhammad adalah simbol al-Insān al-Kämil. Sufi percaya bahwa syafa'at dapat diterima dari Muhammad, bahkan di dunia ini. Para sufi percaya bahwa Muhammad mendengarkan mereka ketika mereka memanggilnya. Para sufi berusaha untuk memiliki hubungan spiritual dengan Muhammad dan berusaha melihat Muhammad dalam mimpi adalah praktik sufi yang umum. Sufi menganggap Muhammad sebagai al-Insān al-Kāmil, manusia sempurna utama yang mencontohkan simbol moralitas Tuhan (Munn, 1969: 279281) dan melihatnya sebagai pemimpin dan pembimbing spiritual utama mereka.

Para pembelajar sufi melacak sebagian besar ajaran asli mereka dari Muhammad melalui sepupu dan menantunya yaitu Ali Karromallah Wajhah. Sufi adalah tanda asketisme karena keterikatan mereka pada dzikir, praktik zikir Allah, yang sering dilakukan setelah sholat. Mereka mendapatkan penganut di antara sejumlah Muslim sebagai reaksi terhadap keduniawian pada awal kekhalifahan Umayyah (661-750) dan telah membentang kebeberapa benua dan budaya lebih dari satu milenium, awalnya mengekspresikan keyakinan mereka dalam bahasa Arab dan kemudian berkembang kedalam bahasa antara lain, Persia, Turki, dan Urdu (Brown, 2014: 58). Sufi memainkan 
peran penting dalam pembentukan masyarakat Muslim melalui kegiatan pendidikan mereka. Menurut William Chittick, dalam arti luas tasawuf dapat digambarkan sebagai interiorisasi, dan intensifikasi keyakinan dan praktik Islam. Manifestasi utama dan kristalisasi esoterisme Islam yang paling penting dan sentral adalah ditemukan dalam makna dan simbol-simbol tasawuf. Sufisme sama tuanya dengan Adam dan esensi dari semua agama (Chittick 1995: 102-109).

Perintah tradisional sufi selama lima abad pertama Islam semuanya berbasis di Islam Sunni. Tasawuf membangkitkan minat yang cukup besar di antara orang-orang terutama karena mistisisme yang terkait dengannya, dan juga karena tidak banyak diketahui tentang rahasia pengetahuan mereka. Namun, sering kali orang-orang, yang melambangkan simbol tasawuf untuk menjalankan adat istiadat dan ritual tertentu tetapi yang tidak memahami arti simbol sebenarnya dari tasawuf, menyesatkan mereka. Sufisme bukanlah sesuatu, yang dapat dijelaskan secara teoritis: itu hanya dapat dipahami melalui partisipasi dan praktik. Sufisme telah memberikan kontribusi signifikan terhadap elaborasi perspektif teoretis dalam banyak domain upaya intelektual. Misalnya, doktrin pusat-pusat kognisi halus (dikenal sebagai Lataif-e-sitta) membahas masalah kebangkitan intuisi spiritual. Idries Shah menyatakan bahwa tasawuf bersifat universal, akarnya mendahului kebangkitan Islam dan Kristen (Shah, 1970: 14-15). Ia mengutip Suhrawardi yang mengatakan bahwa tasawuf ini adalah suatu bentuk kebijaksanaan yang diketahui dan dipraktikkan oleh suksesi orang bijak termasuk Hermes seorang misterius kuno dari Mesir.

Tujuan penelitian ini untuk membuka esensi sufi dalam Islam dan memahami konsep inti syari'at sebagai ajaran spiritual terdalam Nabi Muhamad untuk menemukan keheningan qolbu mu'min baitullah melalui analisis semiotika. Terlepas dari penurunan relatif ajaran sufi di era modern dan kritik terhadap beberapa aspek sufisme oleh pemikir modernis dan salafi konservatif, tasawuf terus memainkan peran penting di dunia Islam, dan juga telah mempengaruhi berbagai bentuk spiritualitas di bangsa Barat, baik Yudaisme maupun Islam.

\section{B. LANDASAN TEORI}

Artikel ini menggunakan teori semiotika Charles Morris dan Pierce. Berdasarkan "semiosis" hubungan antara tanda, objek, dan makna, tanda itu mewakili objek. Interpretant mengacu pada tanda yang berfungsi sebagai representasi dari suatu objek. Tanda dapat berupa (kata-kata) verbal atau non verbal (Pierce, 1958: 167). Sementara semiotika menurut Charles Morris (1987: 23-57), setiap orang adalah penafsir tanda. Tanda yang memandu seseorang dalam menginterpretasikan kata, gambar, dan juga gerakan tubuh yaitu dari segi aspek designative, ini mengarahkan penerjemah kekajian makna simbol lapaz zikir Allah dan makna gerakan ritual dalam zikir dan do'a. Menurut Morris, tindakan manusia melibatkan tanda dan makna melalui persepsi yaitu orang menjadi sadar akan suatu tanda, menafsirkan dan menjelaskannya. Simbolisme yang mendasari pemahaman dan pengetahuan semua manusia. Simbol adalah alat untuk konsepsi objek. Simbol adalah "instrumen pemikiran" yang memungkinkan seseorang untuk memikirkan sesuatu selain dari kehadirannya yang segera Morris (1987:57). Simbol menjadi bermakna dalam wacana. Simbol dapat bersifat diskursif atau non-diskursif. Simbolisme diskursif adalah pemikiran dan makna berbasis bahasa Simbolisme. Simbolisme Non-Diskursif adalah emosi dan makna non-verbal: seni, musik, tarian dan gerakan tubuh lainnya. Makna dapat ditemukan dalam simbolisme non-diskursif dan diskursif. Setiap tanda memiliki makna dan potensi untuk banyak makna. Beragam makna dipengaruhi secara sosial dan budaya. Tanda memiliki makna denotatif dan konotatif yang melibatkan katakata, emosi dalam menafsirkan makna gerakan tubuh ritual zikir esoterik Sufi.

Gagasan dasar dalam praktik ini adalah untuk memvisualisasikan Allah sebagai simbol yang telah ditulis dihati murid. Tarekat sufi Naqshabandi ini percaya pada 
prinsip-prinsip dasar Islam, tetapi ditafsirkan melalui pengalaman mistis dan simbol-simbol ketuhanan (Kabbani, 2004: 644). Jika dzikir Allah diucapkan berulang kali penuh perasaan, dapat membawa kedamaian yang luar biasa kedalam tubuh seorang salik yang melibatkan tanda emotif ketuhanan. Lapaz Allah sebagai suara benih alam semesta dan simbol-simbol Tuhan. Jika kita terus menerus diganggu oleh pikiran liar kita dalam berzikir, kita dapat memaksa pikiran untuk memikirkan hanya satu kata yaitu lapaz Allah, jauh lebih mudah untuk berkonsentrasi pada satu kata, daripada tidak berpikir sama sekali atau mengosongkan pikiran (Kabbani, 2004: 645).

Merasakan keheningan di dalam dzikir merupakan perintah bagi seorang salik dalam merasakan keheningan batin yang merupakan pusat dan sumber dari Nur Allah-Nur Muhammad, Sifat Allah-Sifat Muhammad, Cahaya Allah-Cahaya Muhammad, Sir AllahSir Muhammad. Perintah sufi didasarkan pada "bay'ah" mubaya'ah "janji, kesetiaan" yang diberikan kepada Muhammad oleh sahabatnya. Dengan berjanji setia kepada Muhammad, para sahabat telah berkomitmen untuk taat kepada Tuhan (Ernst, 2010: 130). "Sesungguhnya, orang-orang yang memberikan Bai'âh (janji) kepadamu (ya Muhammad) berarti mereka telah memberikan Bai'âh (janji) kepada Allah. Tangan Allah ada diatas tangan mereka. Lalu barangsiapa yang melanggar janjinya, mematahkannya hanya untuk kerugiannya sendiri, dan barang siapa memenuhi apa yang telah ia janjikan dengan Allah, Ia akan memberinya pahala yang besar" (Surah AlFathu: 10).

\section{METODE}

Artikel ini menggunakan metode analisis deskriptif. Kami menganalisis makna hurufhuruf Lapaz zikir "ALLAH" dan makna gerakan tubuh ritual zikir Sufisme. Sumber data yaitu Tafsir Al-Mukhtasor, (1439 H). AlMarkaz Liddirosaatil Qur'aniyyah: AlMukhtasor fi Tafsiiril Qur'anil Kariim/ Tasnip : Jama'atin min Ulama' it Tafsiir. I Nukhbah minal ulama'. Thob'ah. 4. Riyadh, yaitu simbol-simbol huruf "Alif, Lam awal, Lam tsani dan simbol huruf $\mathrm{Ha}$ " dan isyarat gerakan ritual zikir sufisme kemudian kami analisis, menjelaskan, dan menyimpulkannya.

Penelitian semiotika yang relevan dengan penelitian ini seperti yang telah diteliti oleh Suko Winarsih dengan judul penelitian "Representasi Bahasa dalam Pertarungan Simbolik dan Kekuasaan'. Namun artikel ini membahas representasi semiotika kebenaran melalui makna simbol yang universal dalam hubungannya dengan mekanisme sosial antara kekuatan dan pelecehan sosial (Winarsih, 2013:11-24).

Dan oleh peneliti Ery Agus Kurnianto di Balai Bahasa Provinsi Sumatera Selatan dengan judul penelitian Analisis Tiga Tataran Aspek Semiotik Tzvetan Todorov Pada Cerpen' Pemintal Kegelapan' Karya Intan Paramaditha. Pada penelitian cerpen"' Pemintal Kegelapan'” ini membahas segi-segi struktur karya yaitu dari aspek sintaksis, aspek semantik dan aspek verbalnya. Kurnianto (2015:206-216). Berbeda dengan penelitian ini yang membahas semiotika dari makna simbol lapaz zikir "ALLAH' dan makna simbol dari gerakan sufi dalam ritual do'a dan zikir masih belum diteliti oleh peneliti lain.

\section{HASIL DAN PEMBAHASAN \\ 1. Muraqaba}

Praktik muraqaba dapat disamakan dengan praktik meditasi yang dibuktikan di banyak komunitas agama. Sementara ada satu uraian tentang praktik dalam garis keturunan Naqsyabandi berbunyi yaitu, Ia harus mengumpulkan semua indera jasmaninya dalam konsentrasi, dan untuk melepaskan diri dari semua keasyikan dan gagasan yang menimbulkan perasaan pada hati. Dengan demikian ia harus mengalihkan kesadaran penuhnya kepada Tuhan Yang Maha tinggi sambil mengatakan tiga kali: "Ilahi anta maqsudi wa-ridaka matlubi: Ya Tuhan ku, Engkau adalah Tujuan ku dan kesenangan baik Mu adalah yang aku cari" (Ernst, 2010: 130). Kemudian dia membawa ke dalam hatinya nama Allah dan ketika terus mengalir dalam hatinya, dia tetap memperhatikan 
maknanya, yaitu "Essence without likeness". Pencari tetap sadar bahwa Dia Hadir, Waspada, Meliputi semua, dengan demikian mencontohkan makna perkataannya (semoga Tuhan memberkatinya dan memberinya damai)" (Ernst, 2010: 130). "Sembahlah Tuhan seolah-olah Anda melihat-Nya, karena jika Anda tidak melihat-Nya, Dia melihatmu". Dalam tradisi kenabian dijelaskan bahwa "Tingkat iman yang paling disukai adalah mengetahui bahwa Allah adalah saksi atas amaliahmu, dimanapun kamu berada" (Tafsir Al-Mukhtasor $1439 \mathrm{H}$ : Bab; Fadho'il Qur'an: 2-13). Ketulusan, kejujuran, dan niat baik adalah kebajikan penting dalam ajaran Islam. Mereka harus membimbing perilaku kita disetiap tingkatan: dengan Allah, dengan orang-orang, dan dalam diri kita sendiri.

Sufi secara historis menghormati Muhammad sebagai kepribadian utama simbol kebesaran spiritual. Penyair sufi Saadi Shirazi menyatakan bahwa "dia yang memilih jalan yang bertentangan dengan jalan Nabi, tidak akan pernah mencapai tujuan". Wahai Saadi, jangan berpikir bahwa seseorang dapat memperlakukan jalan kemurnian itu kecuali setelah orang yang dipilih (Aavani, 2004: 4). Yaitu pemahaman langsung dengan simbol hadirat Ilahi yang mengarahkan ke kesadaran spiritual (Kabbani, 2004: 557). Jenis dzikir yang dipraktikkan oleh para Sufi mengasumsikan bahwa ada sesuatu di dalam hati manusia yang menghubungkan kita dengan simbol-simbol sumber Ilahi. Melalui zikir keheningan inilah memungkinkan Muhammad untuk menerima dan mengkomunikasikan wahyu. Wahyu diperuntukkan bagi para Nabi, tetapi hubungan hati dengan Yang Ilahi jelas merupakan hak asasi semua manusia.

\section{Semiotika Di Dalam Zikir Sufi}

Semiotika adalah studi tentang bagaimana orang membuat makna melalui cara-cara linguistik dan non-linguistik. Ini adalah teori filosofis yang berkaitan dengan memahami bagaimana orang menggunakan tanda dan simbol dalam pembuatan makna. Sistem tanda meliputi kata, gambar, angka, dan objek. Tanda-tanda ini memiliki makna hanya karena orang-orang telah menyetujui dan menggunakan maknanya. Seseorang yang mempelajari atau mempraktikkan semiotik dikenal sebagai semiotik. Banyak istilah dan konsep yang digunakan oleh ahli semiotik kontemporer diperkenalkan oleh ahli bahasa Swiss Ferdinand de Saussure (1857-1913). Saussure (1916: 65-70) mendefinisikan tanda sebagai gerakan, gambar, pola, atau peristiwa apapun yang menyampaikan makna. Langue didefinisikan sebagai struktur atau tata bahasa sebagai pilihan aktual yang dibuat oleh pembicara untuk mengkomunikasikan informasi itu.

Semiotika adalah kunci studi dalam berpikir tentang evolusi kesadaran manusia. Filsuf Inggris John Locke (1632-1704) mengaitkan kemajuan kecerdasan dengan tiga langkah: memahami sifat hal-hal, memahami apa yang harus dilakukan untuk mencapai apapun yang ingin Anda capai, dan kemampuan untuk mengkomunikasikan halhal ini kepada yang lain. Bahasa dimulai dengan tanda-tanda. Dalam terminologi Locke (1951: 386-399) mengatakan bahwa tanda-tanda bersifat diadik yaitu, tanda terikat dengan makna tertentu. Charles Sanders Peirce (1839-1914) menggambarkan bahwa tanda-tanda hanya berfungsi jika ada kecerdasan yang mampu belajar dari pengalaman. Konsep Peirce (2002: 108) tentang semiotika adalah triadik, yaitu tanda, makna, penerjemah. Semiotik modern melihat seluruh jaringan tanda disekitar kita, tanda atau simbol yang memiliki arti berbeda dalam konteks yang berbeda, bahkan tanda atau simbol yang bersuara. Seperti simbol dalam suara sirene Ambulan; coba pikirkan apa yang dikomunikasikan sirene ambulan kepada Anda saat Anda mengemudi: memiliki banyak makna seperti "Seseorang terancam bahaya dan kami sedang terburuburu untuk sampai kesana. Menepi ke sisi jalan dan biarkan kami lewat atau kami akan melacak Anda dan mendenda Anda".

Semiotika adalah studi tentang tanda dan simbol, khususnya ketika mereka mengkomunikasikan hal-hal yang diucapkan dan tidak diucapkan. Dalam konteks ini lafaz 
dan gerakan zikir para sufi memiliki makna dan simbol yang dipraktikkan oleh para pencari spiritual. Praktisi dzikir Sufi ketika duduk bersila menghadap qiblat adalah bentuk simbol atau makna ketundukan secara fisik meditasi yang berasal dari para Sufi. Praktik ini masih dipraktikkan oleh para Sufi Naqshabandi di seluruh dunia sampai saat ini. Ini adalah kebiasaan yang dilakukan dalam setiap praktik dzikir diamnya yang melaluinya para sufi Naqshabandi juga disebut khalwat yaitu, bertujuan untuk mencapai sumber dari semua kesempurnaan atau kamal. Ini yang dicari seseorang dengan meninggalkan nafsu, ego atau keinginan pribadi dengan mendengarkan suara batin fokus dengan dzikir Allah dan hening di dalam pikiran dan hati seorang praktisi dalam duduk diamnya yang berulang-ulang melafalkan kalimah Ilahi di dalam batin yang telah dilihat oleh seorang salik sebagai imitasi simbolis dari hubungan dunia zahir dan dunia batin, atau komunikasi hamba dengan Tuhan di dalam keheningan dan kekosongan. Menurut Peirce dalam Pietarinen, (2004: 295315), bahwa memaknai dan menerjemahkan tanda dan simbol ketuhanan dan strategi komunikasi yang diadopsi oleh para pemikir teologi berasal dari teori tanda Charles Sanders Peirce dan logika pragmatis dan filsafatnya. Hal ini merupakan asumsi dasar bahwa pemahaman komunikasi melalui semiotika merupakan pandangan yang intensif dan bijaksana antar lintas disiplin ilmu.

Menurut pandangan Peirce dalam Dewey (1946: 85-96) bahwa beberapa makna dalam ucapan dan gerakan memiliki makna emotif dalam teori fakta tentang tanda-tanda dan linguistik. Dijelaskan oleh para Sufi dalam simbolisme ritual dzikir diam, yaitu simbol topi penutup kepala melambangkan batu nisan ego, simbol baju lengan putihnya yang lebar melambangkan penutup ego, simbol sarung warna putih melambangkan kafan ego. Dengan melepaskan simbol sorban hitamnya diatas kepala ia secara spiritual terlahir kembali ke kebenaran, duduk khalwat di atas simbol sorban putih melambangkan aktifitas manusia harus dimulai dari hati yang tulus ikhlas karena Tuhan semata dan terhindar dari noda dan benda-benda duniawi yang najis dan haram. Dengan memegang simbol tasbih sambil berdzikir melapalkan lafaz Allah berulang-ulang melambangkan seorang anak yang masih bocah yang sedang dituntun berjalan memegang tongkat sebagai penuntun. Artinya seorang pembelajar pemula sufi memegang simbol tasbih supaya bisa mengucapkan lafaz Allah secara berulang-ulang, kalau sudah terbiasa berdzikir dengan tasbih, maka seorang salik akan bisa berdzikir tanpa tasbih.

Sama halnya seperti anak bocah yang sudah bisa berjalan tanpa memegang tongkat, maka dia akan berlari tanpa dituntun. Duduk sendiri di atas simbol sajadah melambangkan untuk mewakili orang nomor satu, dengan demikian bersaksi tentang kesatuan dan keEsaan Tuhan. Wajah dan dadanya diarahkan kearah simbol qiblat melambangkan siap menerima kebaikan Tuhan dari kehadiran Tuhan yang tak terlihat. Dzikir didalam hening merupakan karunia rohani Tuhan kepada mereka yang menyaksikan kesaksian cahaya Ilahi di keheningan. Menyebut Allah didalam hati, melambangkan merangkul semua manusia dengan cinta. Manusia telah diciptakan dengan cinta untuk mencintai. Maulana Jalaluddin Rumi mengatakan, "semua cinta adalah jembatan menuju cinta Ilahi. Namun, mereka yang belum merasakannya tidak akan pernah tahu". Pentingnya ilmu tanda dan simbol telah diakui secara luas, tetapi hanya segelintir peneliti yang mengembangkan teori dan penelitian berdasarkan semiotika (doktrin tanda) (Mick, 1986:196-213).

Berdasarkan paparan semiotika zikir sufi ini menjelaskan manfaat dan bagaimana memahami semiotika kematian yang dalam simbol wacana Al-Qur'an disebutkan yaitu, "Siapa yang di dunia ini masih buta, maka di akhirat akan lebih buta lagi dan tersesat jalan dari kebenaran" (Al-Isro': 72). Dalam tafsir Al-Mukhtasor (1439 H: 289) dijelaskan bahwa siapa yang di alam dunia ini hatinya buta dari simbol kebenaran, maka di akhirat lebih buta lagi dari simbol-simbol ketuhanan dan tidak mendapat jalan petunjuk ke surga 
dan tersesat jalan dari hidayah Allah dan akan mendapatkan balasan amalnya dengan siasia”. Ayat ini adalah kode simbolis Diskursif yang melibatkan emosi dan makna Verbal (Langer, 1942: 1357-1386). Untuk menyadari hakekat kematiannya sendiri yang pasti mereka akan hadapi dan lalui.

Kematian adalah nyanyian sunyi dikeheningan, meninggalkan dan ditinggalkan oleh hidupnya Roh dan Nyawa. Dalam proses kematian manusia harus mengetahui dan merasakannya, karena akan hidup penyempurnaan lagi dialam abadi. Dalam bahasa krinilisme yaitu bahasa asli Sansekerta didalam kitab keheningan, Gaos Sutasoma dengan syairnya pernah berujar tentang simbol kepribadian yang dalam, atau makna simbolisme Diskursif (Langer, 1942: 13571386). Yaitu "Ma ning roso ning makrifah, Tatah ne Ing ling Nguarse, sing sejati maturing, asi ning wacane" (Sutasoma, 1952: 12). Penulis terjemahkan secara bebas yaitu, "siapa yang tidak merasakan, maka dia tidak akan tahu, setelah beberapa saat mengalami kematian manusia harus mampu mengingat kembali rasa kematiannya, ini yang harus dipahami untuk bisa selamat menghadap kepada Tuhan, ini yang harus dijelaskan dan dipelajari bagi siapa yang mampu menjelaskan dan mempelajarinya". Makna simbol wacana syair Gaos Sutasoma ini adalah tentang representasi kematian dan bagaimana menghadapinya.

Semiologi mengkaji studi bahasa dan fungsinya sebagai bagian dari penggunaan tanda-tanda yang terintegrasi dalam komunikasi manusia. Sebagai contoh pendekatan tekstualisasi. Di sini bahasa melengkapi dan dilengkapi dengan tandatanda non-linguistik dalam interelasi yang sangat kompleks. Tekstualisasi dipilih untuk studi karena dunia modern semakin bergantung pada kompetensi sosial yang diselenggarakan melalui teks. Teks (tertulis, dicetak, diukir dan lain-lain) berfungsi secara siginifikan dalam cara-cara yang tidak cukup dijelaskan dengan memberikan akun sempit linguistik tentang apa yang dikatakan teks. Tekstualisasi adalah praktik budaya yang tidak dapat dijelaskan dengan memperlakukan bahasa sebagai independen secara semiologis. Tekstualisasi semiologi jauh melampaui pemahaman membaca dan menulis. Implikasi dari pendekatan terhadap semiologi memiliki konsekuensi penting bagi definisi kita tentang tanda lingusitik itu sendiri (Harris, 1984: 271286).

Dalam pandangan Peirce didalam Huang (2006: 1-7) bahwa makna simbol dalam wacana syair Sutasoma ini adalah makna pragmatis yaitu bagaimana individu membuat dan memahami makna, sehingga pengetahuan yang diperoleh menjadi berguna untuk mengatasi tantangan yang diberikan oleh lingkungan sekitarnya. Peirce (1960), menciptakan pendekatan triadik dalam menyelidiki hubungan antara penafsir cerdas, alat simbol, dan makna kebenaran untuk mengetahui dan menjelaskan keadaan untuk mengekspresikan makna dalam suatu lingkungan. Simbol kematian atau saat sakaratul maut ini yang oleh Imam Ali menyebutnya dengan "Saah al-Dalli ila Dzatil Baqo'il wujud". (saat hening menuju ke alam yang kekal) yaitu, "dimana keadaan itu harus dihadapi dengan jiwa yang tenang, ketika Roh dan Nyawa itu berpisah dari jasad menuju ke Dzat wajibul wujud yang Maha Baqo' (kekal)".

Dalam buku pedoman spiritual dituliskan bahwa "jika engkau ingin mengenal alam abadi, maka kenalilah simbol di alam pribadimu. Jikalau engkau belum mengenal simbol alam pribadimu, maka masih jauhlah alam abadi itu darimu". Ungkapan ini merupakan aksioma untuk memperhatikan tanda dan simbol yang ada di dalam diri dan alam semesta. Dalam wacana Al-Qur'an (Surah Qof: 19) disebutkan bahwa "Dan pasti sakaratul maut itu akan datang yang dahulu didunia kamu ingin menghindarinya". Dalam kitab Tafsir Al-Mukhtasor (1439 H: 519) dijelaskan kepada manusia yang belum menyadari kode ayat-ayat Allah yang merupakan perintah untuk mengenal simbol kematian, bahkan ingin menghindari dan melalaikannya. Dalam ayat Agung ini memiliki pesan makna simbolis untuk memahami simbol-simbol ketuhanan dengan lebih mendalam bahwa kematian bukan 
hanya untuk ditangisi, kematian bukan sebatas tragedi, kematian bukan untuk ditakuti tetapi bagaimana menghadapi kematian itulah yang diteliti, maka kenalilah simbol ketuhanan yang ada didalam dirimu. Di dalam Kamus Al-Munawwir (1997: 644), menjelaskan kata "Sakarat" memiliki akar kata dari "Sakkaral Baba" "menutup pintu", yaitu menutup pintu kehidupan menuju alam kematian, atau menutup pintu kematian menuju alam keabadian atau (mati yang mencari hidup ataukah hidup yang mencari mati). Sakarat adalah sebuah kata atau kode objektif bagi semua makhluk hidup yang akan berpindah dari alam dunia ini ke alam kematian. Simbol kata sakarat di sini seperti yang diungkapkan oleh Peirce di dalam Dewey (1946: 85-95) bahwa makna kata dalam ucapan dan gerakan memiliki makna "emotif". Yaitu pada kata sakarat adalah simbol yang memiliki makna emotif dimana matinya keadaan hidup, pada saat itu adalah peristiwa pertama dan terakhir yang akan dilalui oleh setiap manusia dan peristiwa soal dan jawab antara manusia dan malaikat Izrail, pada saat itulah titik awal yang sangat berat dirasakan oleh manusia untuk menuju alam kematian dan tidak ada cara lain untuk bisa menghadapinya dengan selamat kecuali dengan jiwa yang murni yaitu jiwa yang telah terzikirkan di dalam hidup. Kematian di dunia ini adalah proses kehidupan manusia menuju hidup abadi, dalam konteks ini apakah manusia akan mampu berjalan menuju keabadian ataukah masih samar dari pengetahuan tentang kematian karena amalanamalan yang dianggap baik dan agama yang telah diyakininya di dunia tidak mampu untuk menjelaskan hakekat tentang kematian dan keabadian, sehingga jiwa mereka masih terkungkung dalam keraguan dan ketakutan dari alam kematian (Al-Ghazzali. 1980: 378).

Tidak hanya dikalangan studi estetika musik di Cina tentang kategori fungsi tanda CS Pierce dan pengikutnya Ch. Morris, namun bagi para sufi dalam memahami makna dan simbol lapaz zikir merupakan bidang teori Peirce yang paling relevan (Monelle, 1991: 99-108). Seorang salik berzikir didalam batinnya dengan lapaz Allah.
Lapaz Allah terdiri dari empat simbol huruf hijaiyyah (abjad Arab) yaitu simbol Alif, Lam awal, Lam Tsani dan huruf Ha'. Simbol Alif ini melambangkan api yang selalu berdiri, karena api ketika menyala selalu berdiri, yang menandakan sifat Tuhan yang Maha Kesendirian Yang Maha Hidup dan Allah Yang Maha Tunggal. Ahli sufi menyebutnya dengan Alifudzzat Saariyun Sirruha fi Kulli Dzarroh, yaitu "Alif Dzat Allah yang mesra rahasia-Nya di setiap molekul-molekul terkecil di alam semesta ini”. Simbol huruf Alif ini memiliki makna "Innani Anallah La Ilaha Illa Ana Fa'budni", yaitu“ Sesungguhnya Aku adalah Allah tidak ada Tuhan yang berhak disembah selain Aku, maka sembahlah Aku yang maha Esa dan tunaikan solat atas kesempurnaan zat ku dan ingatlah $\mathrm{Aku}$ didalam solat mu (AlMukhtasor: 313)". Dari simbol sifat Alif ini Allah mulai berfirman kepada alam dunia ini, yang di dalam syair sufi disebut dengan Alif $\mathrm{Hu}$ Sabdening Allah, Alif $\mathrm{Hu}$ Sabdening Allah, yaitu dengan kemurnian simbol sifat Alif yang berdiri sendiri melaluinya Allah mengeluarkan firman-firmanNya. Simbol Huruf Lam awal melambangkan sifat Tuhan yang memiliki kekuasaan untuk meliputi alam semesta. Didalam Tafsir Al-Mukhtasor (1439: 98) dijelaskan bahwa " hanya Allah yang memiliki segala apa yang ada di langit dan apa-apa yang ada di bumi, Allah meliputi segala sesuatu dari semua pengetahuan makhlukNya. Dialah yang maha mengatur dan menentukannya'. Simbol Huruf Lam tsani melambangkan sifat Tuhan yang memiliki kekuasaan untuk mengisi alam semesta. Disebutkan didalam Al-Qur'an "' Dia-lah Allah, yang menjadikan segala yang ada di bumi untuk kamu dan Dia berkehendak (menciptakan) langit, lalu dijadikan-Nya tujuh langit. dan Dia Maha mengetahui segala sesuatu" (Al-Baqarah [2] : 29). Adapun simbol huruf $\mathrm{Ha}$ ' melambangkan sifat Tuhan yang memiliki sifat tanpa batas di alam kekosongan dan keheningan. Dalam salah satu hadis qudsi, Allah berfirman; Dalam setiap anak Adam, Aku ciptakan mahligai yang disebut dada, di dalam dada ada qolbu, di dalam qolbu ada 
fu'ad di dalam fu'ad ada syagofa, di dalam syagofa ada sir, di dalam sir ada Aku, tempat Aku menyimpan rahasia. Fu'ad adalah salah satu dari bagian hati, yaitu hati yang bersih dan suci, syagofa letaknya lebih dalam dari fu'ad, di dalamnya ada nurani, didalam nurani ada Aku, ada Allah, ada cahaya yang maha melihat. (Al-Qiyamah: 14). Inilah bukti objektif bahwa Allah meliputi segala ruang dan waktu di alam semesta.

Dalam pandangan Morris di dalam Posner. (1987: 23-57) bahwa tindakan manusia tidak terpikirkan tanpa proses dan evaluasi tanda. Bagaimana mungkin bisa menjadi yang terbaik tanpa memperoleh pemahaman teoritis tentang tanda-tanda dan nilai-nilai dirinya sendiri. Setiap lapaz zikir Allah adalah memiliki makna dan tanda yang juga harus dipahami dan disadari oleh para pencari spiritual, dunia zikir esoterik adalah dunia yang sarat dengan simbol dan makna yang perlu dipahami dengan teliti dan hatihati.

Dalam konteks ini dapat dipahami bahwa seorang penafsir adalah bagian efek dari tanda pada pikiran, atau pada apapun yang bertindak seperti pikiran, apa yang Peirce sebut sebagai pikiran semu. Untuk memperjelas apa yang dimaksud dengan 'pikiran semu', adalah sebuah pemikiran untuk mendapatkan mode aktif apapun harus diwujudkan dalam suatu 'Tanda'. Pikiran adalah tanda variasi khusus. Semua pemikiran adalah semacam dialog yaitu seruan dari diri sesaat ke diri yang dianggap lebih baik, yaitu dari pandangan sendiri ke pandangan yang lebih umum. Karena setiap pemikiran membutuhkan pikiran, maka setiap tanda bahkan jika diluar pikiran pasti semua merupakan tekad dari pikiran semu. Pikiran semu itu sendiri adalah suatu tanda, yaitu suatu tanda yang dapat ditentukan. (The Commens Dictionary:Peirce's Terms in His Own Words. Diaksess online tanggal 26.08.2019).

Seorang penafsir tanda, kata dan huruf dalam simbol-simbol zikir sufi adalah apa yang dihasilkan dari proses penafsiran dan salah satu jenis kegiatan yang berada dibawah ranah semiotik. Peirce didalam Arisbe
(1868:103-114) berpendapat bahwa logika adalah studi formal tentang tanda-tanda dalam arti luas, tidak hanya tanda-tanda yang artifisial, linguistik, atau simbolis, tetapi juga tanda-tanda yang mirip atau bersifat indeksik seperti reaksi. Peirce berpendapat bahwa "semua alam semesta ini disempurnakan dengan tanda-tanda, jika tidak hanya terdiri dari tanda-tanda" maka hubungannya bersama dengan representasional dan inferensial mereka. Dia berpendapat bahwa, karena semua pikiran memerlukan waktu, semua pikiran dalam tanda-tanda: Karena itu, pemikiran itu tidak dapat terjadi dalam sekejap, tetapi membutuhkan waktu, hanyalah cara lain untuk mengatakan bahwa setiap pikiran harus ditafsirkan dalam yang lain, atau bahwa semua pikiran ada dalam tanda-tanda.

Pikiran tidak harus terhubung dengan otak sehingga tidak ada pemikiran tanpa Tanda. Disini kita harus memberi"Tanda" arti yang sangat luas, dalam konteks ini simbol-simbol zikir sufi adalah tanda yang terhubung yang memiliki Quasi-mind, yaitu dapat dinyatakan bahwa tidak ada tanda, kode atau kata yang terisolasi. Selain itu, tanda-tanda membutuhkan setidaknya dua pikiran-Kuasi: Quasi-utterer dan Quasi-interpreter: dan meskipun keduanya bersatu (yaitu, satu pikiran) dalam tanda itu sendiri, mereka harus berbeda. Mereka didalam tanda, bisa dikatakan dilas. Dengan demikian, itu bukan hanya fakta psikologis manusia, tetapi suatu keharusan logika bahwa setiap evolusi pemikiran logis harus dialogis (Eprint, 1906: 492-546).

Sementara proses semiotika triadik Peirce dalam menerjemahkan huruf-huruf, tanda dan simbol ketuhanan adalah bentuk dari panentheisme yaitu bahwa Tuhan meliputi dan menembusi setiap bagian simbol semesta alam dan juga melampaui ruang dan waktu. Dalam pandangan makna simbol semiotika ini Tuhan dipandang sebagai jiwa alam semesta, universal roh hadir melalui simbol dan makna dimana-mana, yang pada saat yang sama esensi simbol ketuhanan "melampaui semua hal yang diciptakan, karena simbol semiotika Tuhan lebih besar 
dari simbol alam semesta dan dalam banyak simbol menunjukkan bahwa alam semesta terkandung didalam esensi Tuhan (Whiting, 1991: viii). Simbolisme dan ikonografi agama masing-masing bentuk dan gerak yang mendasar dan seringkali kompleks digunakan sebagai semacam kunci untuk menyampaikan konsep-konsep keagamaan dan representasi visual, auditori, dan kinetik dari ide dan peristiwa keagamaan. Simbolisme dan ikonografi telah digunakan oleh semua agama didunia. Sejak abad ke-20 beberapa ilmuan telah menekankan karakter simbolik agama daripada upaya untuk menghadirkan agama secara rasional. Aspek simbolis agama bahkan dianggap oleh beberapa peneliti psikologi dan mitologi sebagai ciri utama ekspresi keagamaan (Whiting, 1991: viii).

Semiotika merupakan warisan ilmiah yang perlu dikaji dan diteliti kembali oleh para akademisi. Jalan sufi mengharuskan kita untuk mengalihkan perhatian kita dari kebisingan batin yang menghubungkan kita dengannya, untuk mencapai keadaan hening, dan memperlakukan semua orang dengan toleransi dan rasa hormat, bahkan jika mereka tidak berpikir dan berperilaku seperti kita (Anjum, 2016: 147-165). "Dia" dalam kerohanian merupakan pikiran yang sunyi, terbebas dari gempuran pikiran dan "keheningan batin". Dalam keadaan seperti itu bukan pada level keadaan tidak adanya suara: sebaliknya, dipahami untuk membawa seseorang berhubungan dengan yang Ilahi, realitas tertinggi, atau diri sejati seseorang, sifat Ilahi seseorang. Dalam Islam ada simbol-simbol semiotika atau tulisan kebijaksanaan para Sufi yang menekankan pentingnya didalam menemukan keheningan. Panduan orang bijak Yahudi dalam kehidupan menyatakan bahwa "tradisi adalah pagar pengaman bagi Taurat, pagar pengaman untuk kebijaksanaan adalah keheningan', keheningan batin dapat dilihat sebagai tidak adanya pikiran, atau ruang dimana pikiran dirasakan (Palmquist, 2006:295-315).

\section{E. PENUTUP}

Apapun pengalaman realitas yang ada dibalik simbol-simbol zikir sufi diatas, semua itu pengalaman sakral yang pada hakikatnya dimiliki oleh konsep agama apapun. Studi sejarah agama-agama telah menunjukkan bahwa pada dasarnya merupakan "simbol" yang memediasi dan membentuk kesadaran religius akan realitas dan klaim yang suci. Agama adalah sistem hubungan, sistem simbol dan respons timbal balik, yang koresponden utamanya adalah yang sakral dan kemanusiaan. Simbol tersebut memiliki hubungan yang telah lama terjalin dengan mitos (kisah sakral yang mendefinisikan kondisi manusia dan hubungan manusia dengan yang suci). Aktifitas dzikir adalah refleksi diri seorang salik, tentang Tuhan, manusia dan hubungan dengan alam semesta melalui analisis semiotika, menuju titik hening dalam hidup dan kematian. Tasawuf secara keseluruhan berkaitan dengan pengalaman pribadi langsung seorang salik, dan karena itu kadang-kadang dibandingkan dengan bentuk konsep non-Islam lainnya atau mistisisme.

\section{DAFTAR PUSTAKA}

Aavani, Gholamreza. (2004). Glorification of The Prophet Muhammad in the Poems of Sa'adi. https://www.scribd.com/ document/132479284/Glorification-ofthe-Prophet-Muhammad-PBUH-in-thePoems-of-SHAIKH-Sa-Adi.

Abu Hamid Al-Ghazzali (1980). Ihya' 'Ulumuddin. Bayrut: Dar al-Ma'rifath.

Al-Mukhtasor, (1439 H). Al-Markaz Liddirosaatil Qur'aniyyah: AlMukhtasor fi Tafsiiril Qur'anil Kariim/ Tasnip : Jama'atin min Ulama' it Tafsiir. / Nukhbah minal ulama'. Thob'ah. 4. Riyadh.

Al-Mukhtasor, $(1439$ H). Al-Markaz Liddirosaatil Qur'aniyyah: AlMukhtasor fi Tafsiiril Qur'anil Kariim/ Tasnip : Jama'atin min Ulama' it Tafsiir. / Nukhbah minal ulama'. Thob'ah. 4. Riyadh.

Al-Mukhtasor, $(1439$ H). Al-Markaz Liddirosaatil Qur'aniyyah: AlMukhtasor fi Tafsiiril Qur'anil Kariim/ Tasnip : Jama'atin min Ulama' it 
Tafsiir. / Nukhbah minal ulama'. Thob'ah. 4. Riyadh.

Al-Mukhtasor, (1439 H). Al-Markaz Liddirosaatil Qur'aniyyah: AlMukhtasor fi Tafsiiril Qur'anil Kariim/ Tasnip : Jama'atin min Ulama' it Tafsiir. I Nukhbah minal ulama'. Thob'ah. 4. Riyadh. Bab; Fadho'il Qur'an: 2-13.

Al-Mukhtasor, $\quad(1439$ H). Al-Markaz Liddirosaatil Qur'aniyyah: AlMukhtasor fi Tafsiiril Qur'anil Kariim/ Tasnip : Jama'atin min Ulama' it Tafsiir. I Nukhbah minal ulama'. Thob'ah. 4. Riyadh.

Al-Qur'an Surah Al-Baqarah: 29

Al-Qur'an Surah Al-Isro: 72.

Al-Qur'an Surah Al-Qof: 19.

Al-Qur'an Surah At-Thalaq: 10-11.

Al-Qur'an, Surah Al-Fathu: 10.

Al-Qur'an Surah Al-Qiyamah: 14

Anjum, Tanvir. (2016). "Silencing of Chisti Sufism in the National Narrative in Pakistan". Journal of Asian Civilizations Islamabad. $39 \quad$ (2): 147-165. https://www.academia.edu/35465003/Sil encing_of_Chishti_Sufism in the_Natio nal Narrative in Pakistan_Journal of Asian_Civilizations_Islamabad._Vol._39 No._2_December_2016.

Brown, Jonathan A.C. (2014). Misquoting Muhammad: The Challenge and Choices of Interpreting the Prophet's Legacy. Oneworld Publications.

Burckhardt, Titus. (2009). Art of Islam: Language and Meaning. Bloomington: World Wisdom.

Chittick, William C. (1995). “. In John L. Esposito (ed.). The Oxford Encyclopedia of the Islamic World. Oxford: Oxford University Press.

De Saussure, F. (1916). Nature of the Linguistic Sign. Course in General Linguistics.

Dewey, John. (1946). "Peirce's Theory of Linguistic Signs, Thought, and Meaning". The Journal of Philosophy. 43 (4).
Eprint, (1906). "Rolegomena To an Apology For Pragmaticism". The Monist. XVI (4).

Eprint, Arisbe. (1868). "Questions Concerning Certain Faculties Claimed for Man". Journal of Speculative Philosophy. 2.

Ernst, Carl W. (2010). The Cambridge Companion to Muhammad, Muhammad as the Pole of Existence, Cambridge: Cambridge University Press.

Harris, Roy. (1984). "The Semiology of textualization". Language Science. 6 (2).

Hawting, G. R.. (2002). The First Dynasty of Islam: The Umayyad Caliphate. United Kingdom: Routledge.

Huang, Sheng-Cheng, (2006) A semiotic view of information: Semiotics as a foundation of LIS research in information behavior. Proceedings of the American Society for Information Science and Technology banner. 43 (1).

Huda, Qamar-ul. (2003). Striving for Divine Union: Spiritual Exercises for Suhrawardi Sufis. United Kingdom: Routledge.

Kabbani, Muhammad Hisham. (2004). Classical Islam and the Naqshbandi Sufi Tradition. Islamic Supreme Council of America.

Kurnianto, Ery Agus (2015) Analisis Tiga Tataran Aspek Semiotik Tzvetan Todorov Pada Cerpen''Pemintal Kegelapan' Karya Intan Paramaditha. Jurnal KANDAI. 11 (2).

Langer, Susanne K. (1942). Philosophy In A New Key. A Study In The Symbolism Of Reason, Rite, and Art. Cambridge Massachusetts: Harvard University Press.

Lings, Martin. (2005). What is Sufism? Lahore: Suhail Academy.

Locke, John. (1951). "John Locke: Philosophy and Political Theory". American Political Science Review, 45 (2). https://www.cambridge.org/core/journal s/american-political-sciencereview/article/john-locke-philosophyand-politicaltheory/3851BBA68F07AE4CA4AD5E9 B8195E761. 
Mick, David Glen. (1986). "Consumer Research and Semiotics: Exploring the Morphology of Signs, Symbols, and Significance". Journal of Consumer Research, 13 (2).

Monelle, R. (1991). "Music and the Peircean Trichotomies". International Review of the Aesthetics and Sociology of Music. 22 (1).

Morris, Charles. (1987). Charles Morris and the Behavioral Foundations of Semiotics. In: Krampen M., Oehler K., Posner R., Sebeok T.A., von Uexküll T. (eds) Classics of Semiotics. Topics in Contemporary Semiotics. Boston: Springer.

Munawwir, Ahmad Warson.(1997). AlMunawwir Kamus Arab-Indonesia. Surabaya: Pustaka Progressif.

Munn, Richard C. 1969. "Reviewed work(s): The Sufis by Idries Shah". Journal of the American Oriental Society. American $\begin{array}{llll}\text { Oriental } & \text { Society. } & 89 & \text { (1). }\end{array}$ https://www.jstor.org/stable/598339?seq $=1$ \#page_scan_tab_contents.

Nasr, Seyyed Hossein. (2007). The Essential Seyyed Hossein Nasr, ed. William C. Chittick Bloomington: World Wisdom.

Palmquist, Stephen. (2006). "Silence as the Ultimate Fulfillment of the Philosophical Quest", Journal Hekmat Va Falsafeh, (Journal of Wisdom and Philosophy).

https://www.academia.edu/200408/Silen ce_as_the_Ultimate_Fulfillment_of_the _Philosophical_Quest.

Peirce, Sanders Charles. (2002). The Peirce Seminar Papers. Essays in Semiotics Analysis. Volume. V. New York: Berghahn Books.

Pierce, Sanders Charles. (1958). State of Vermont V. Carroll B. Pierce. Supreme Court of Vermont. Bennington.

Pietarinen, Ahti-Veikko. (2004). "Grice in the wake of Peirce". Journal Pragmatics \& Condition. 12 (2).

Posner, R. (1987) Charles Morris and the Behavioral Foundations of Semiotics. In: Krampen M., Oehler K., Posner R., Sebeok T.A., von Uexküll T. (eds)
Classics of Semiotics. Topics in Contemporary Semiotics. Springer, Boston, MA.

Quasi-mind'. Term in M. Bergman \& S. Paavola (Eds.), The Commens Dictionary: Peirce's Terms in His Own Words. New Edition. Retrieved from http://www.commens.org/dictionary/ter $\mathrm{m} /$ quasi-mind, diakses tanggal: 26.08.2019.

Sutasoma, (1952) Kitab Rahasia Bainal Haq. 12. Tidak diterbitkan.

Shah, Idries. (1970). The Boook of The Way of the Sufi. New York: Dutton. Stjernholm.

Whiting, Robert. (1991). Religions for Today. London: Stanley Thomes.

Winarsih Suko, (2013). "Representasi Bahasa dalam Pertarungan Simbolik dan Kekuasaan". Jurnal Bahasa Lingua Scientia. 5 (1). 